Food Processing and Technology includes set of physical, chemical or microbiological methods and techniques used to transmute raw ingredients into food and its transformation into other forms in food processing industry.

It is an international journal designed to publish original research on various disciplines encompassing the processing and technology of food. It features the significant interest to researchers and scholars for the progress of food science, scope of the journal to provide a complete source of authentic information about the current developments in the field of food processing and technology.
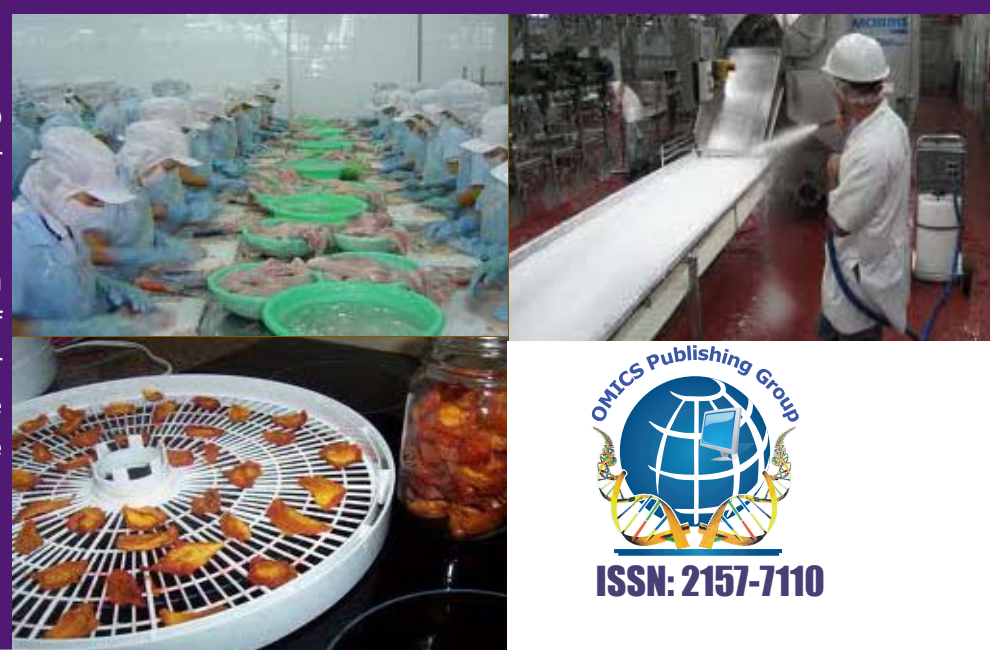

\title{
Journal of Food Processing \& Technology
}

\section{Editors \& Editorial Board}
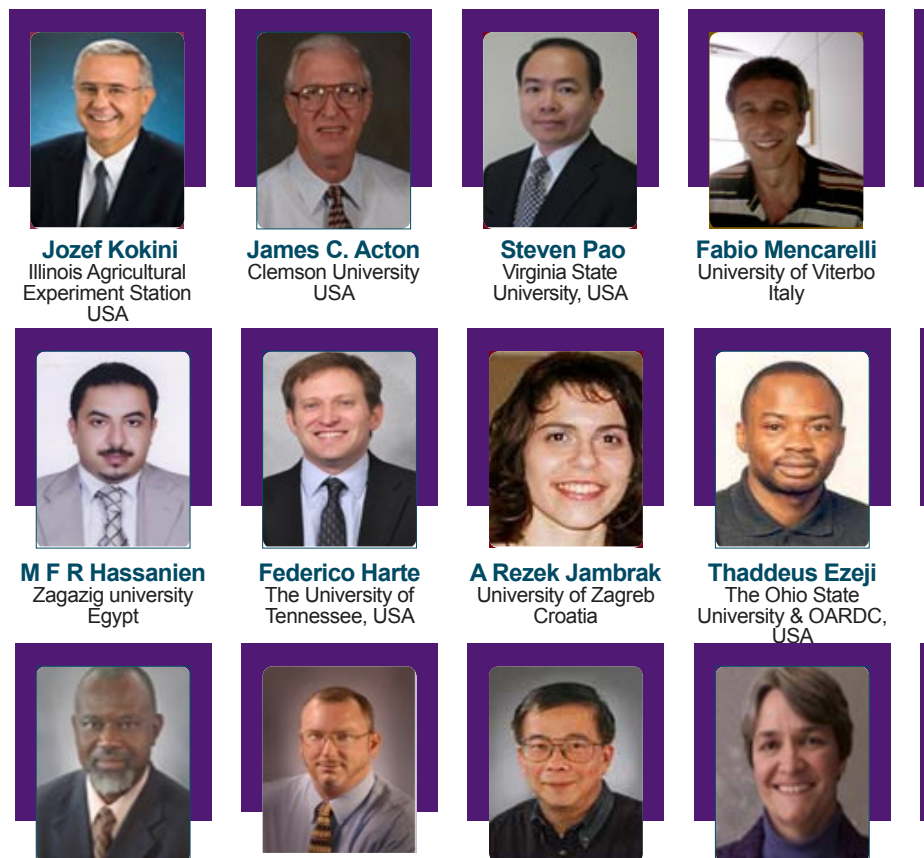

Chris Sommers Eastern Regional
Research Center

Dike O. Ukuku Research Center

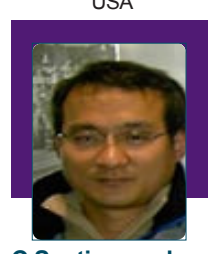

C Santivarangkna Technical University
of Munich, Germany

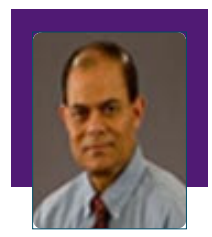

S Mukhopadhyay Eastern Regional Re-
search Center, USA
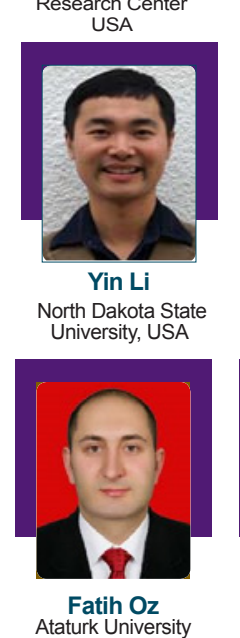
University of Zagreb
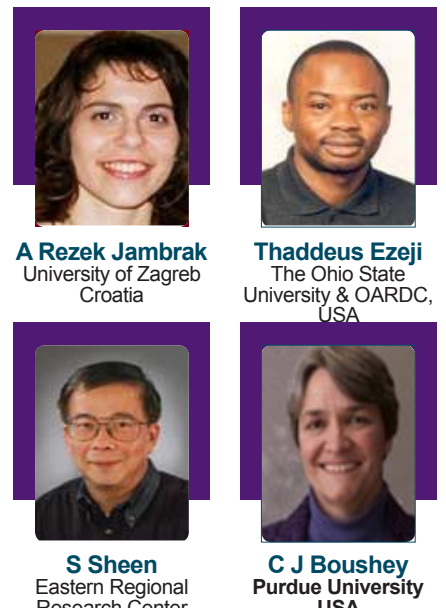

Research Center
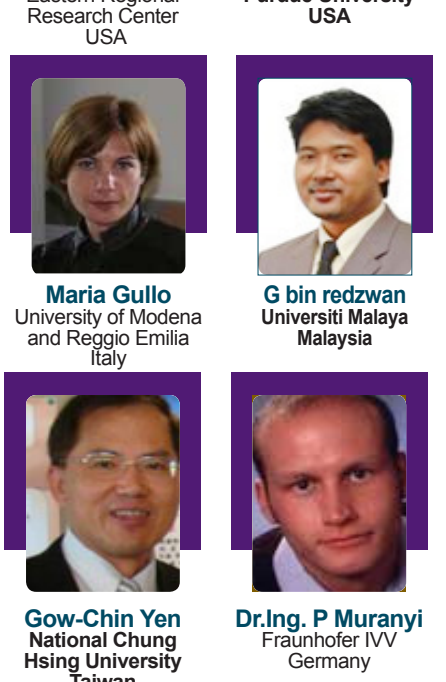
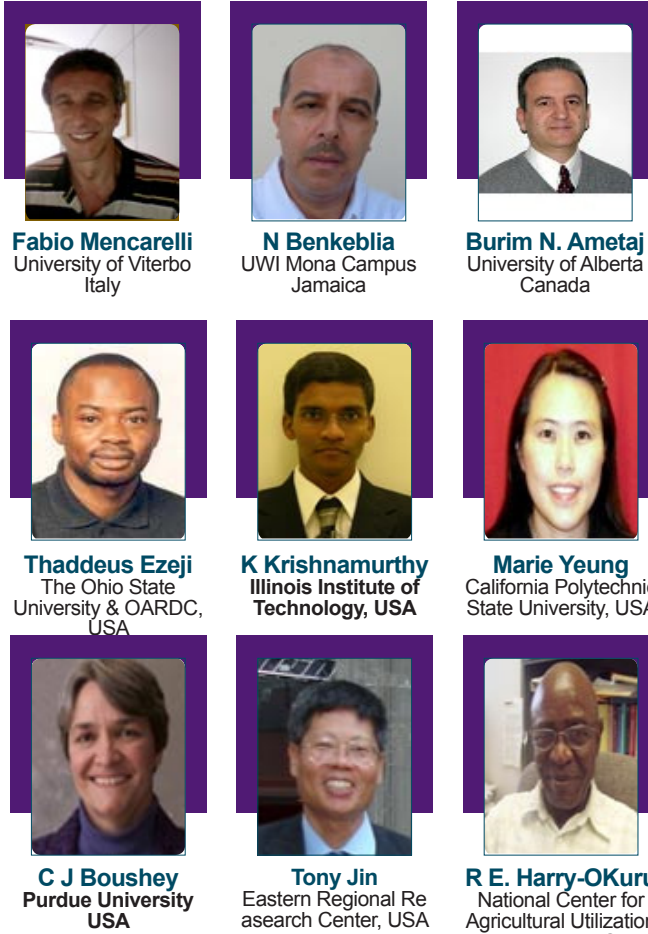

Burim N. Ametaj

Burim N. Ameta

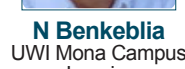

Mona Campus
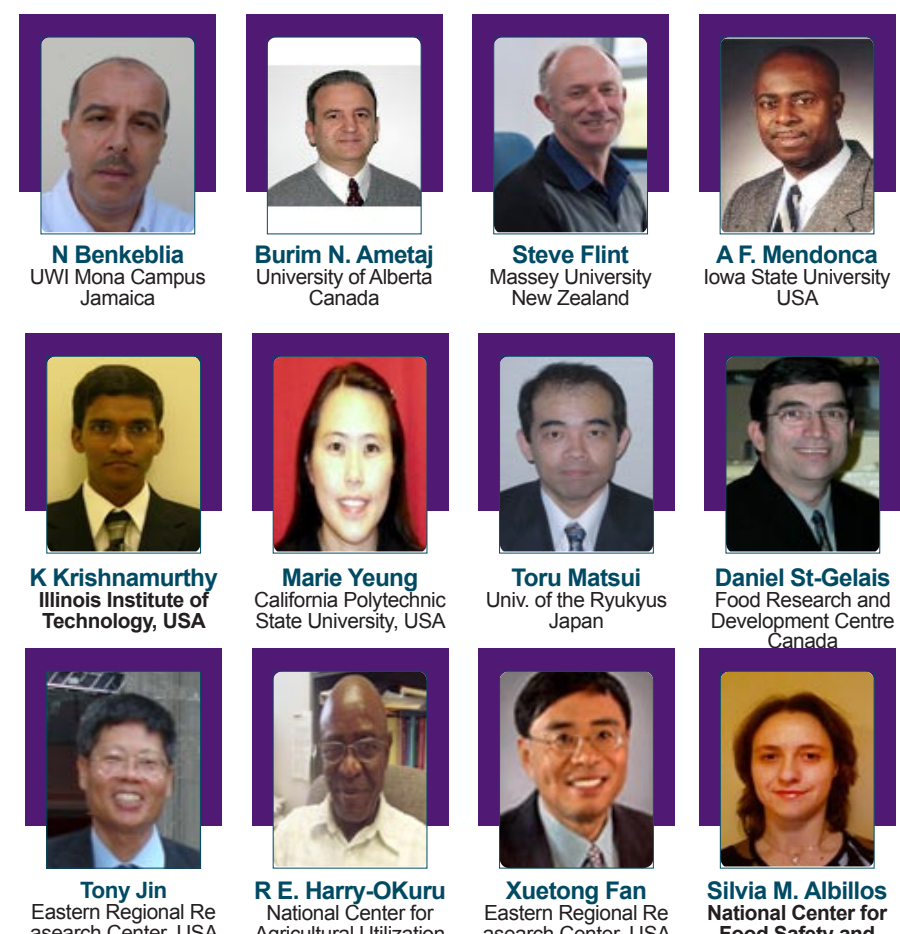

R E. Harry-OKuru

Agricultural Utilizatio
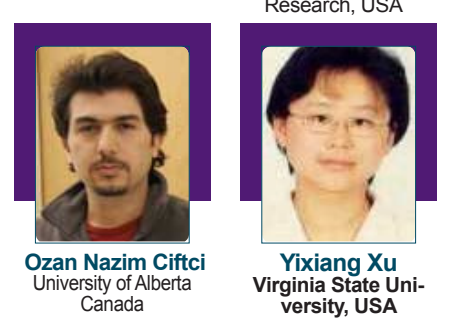
Food Safety and Technology, Argo
Tect
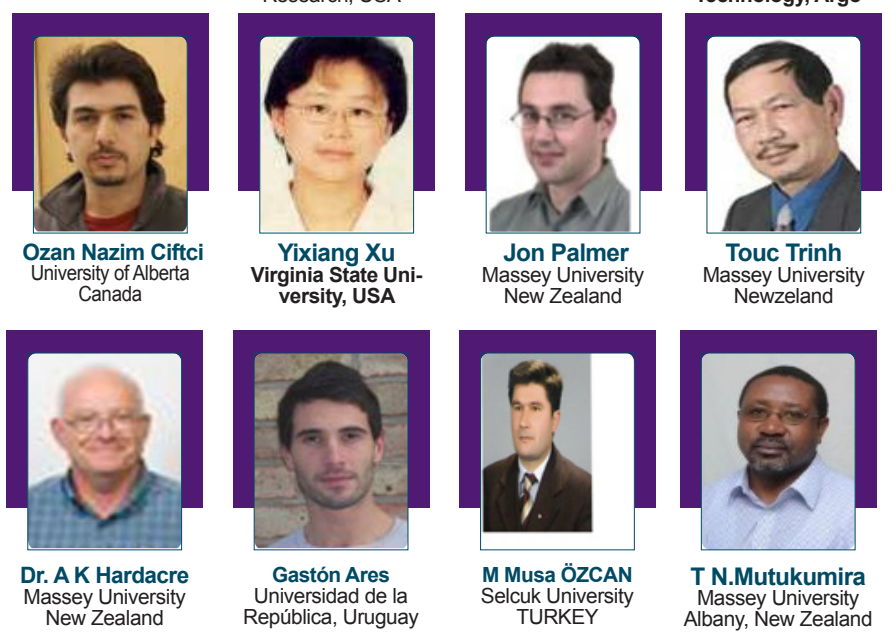

Journal of Food Processing \& Technology - Open Access using online manuscript submission. Submit your manuscript at http://www.omicsonline.org/submission 


\title{
Open Access Open Access Scientific Reports

\section{Studies on Extraction of Essential Oil and Pectin from Sweet Orange}

\section{Syed Hammed Hashmi' ${ }^{1}$ Pravin Ghatge ${ }^{1}$, Girish Marotirao Machewad ${ }^{* 2}$ and Sharad Pawar}

${ }^{1}$ Department of Food Chemistry and Nutrition, College of Food Technology, Marathwada Krishi Vidyapeeth, Parbhani-431 402, Maharashtra, India

${ }^{2}$ Department of Food and Industrial Microbiology, College of Food Technology, Marathwada Krishi Vidyapeeth, Parbhani - 431 402, Maharashtra, India

\begin{abstract}
The essential oil and pectin extraction from sweet orange were studied. The physical characteristics of sweet orange were found color (greenish yellow). The wt of peel, juice, pomace and seed was 47.1, 77.65, 66, 12.6 $\mathrm{g}$ respectively. The yield of essential oil obtained from flavedo peel layer is $3.02 \%$. Further the physicochemical characteristics of essential oil were found yellowish liquid appearance, orange odor, relative density $(21.02 \mathrm{~g} / \mathrm{ml})$, specific gravity $(0.841 \mathrm{~g} / \mathrm{ml})$, solubility in alcohol (soluble in $95 \%$ but insoluble in $90 \%$ ), peroxide vale (3.5), evaporation residue $(4.25 \%)$, flash point $\left(48^{\circ} \mathrm{C}\right)$, aldehyde $(1.3 \%)$ and ester content $(2.0 \%)$. The yield of pectin extracted by acid precipitation method from albedo peel layer was $20.12 \%$. Further the physicochemical characteristics of pectin were found color (brown), moisture content $(3.78 \%)$, ash $(0.62 \%)$, degree of methoxylation $(9.2 \%)$, gel grade $(150 \%)$ and calcium pectate $(7.40 \%)$.
\end{abstract}

Keywords: Sweet orange; Physico-chemical characteristics; Essential oil; Pectin

\section{Introduction}

Citrus is one of the most important fruit crops grown throughout the world. Further it is made up of many species that vary in importance due to different climatic zones. Citrus fruits belong to the plant family Rutaceae sub family Aurantiodeae which comprises 33 well-known genera and 203 species. The true citrus fruit group which has a berry fruit called hesperidium consists of six genera i.e. Citrus fortunella, ponciru, microcitrus, eremocitrus and clymenia. The genus citrus is evergreen unifoliate and consists of two sub-genera, papeda and cucitrus. The fruits of papeda are inedible because of numerous droplets of acrid oil the juice sacs. Eucitrus consists of eight important commercial cultivars grown throughout the world. These are Sweet Orange (Citrus sinensis), Grapefruit (Citrus paradisi), Sour orange (Citrus quarantium), Mandarin (Citrus reticulata), Lemon (Citrus limon), Lime (Citrus aurantifolia), Citron (Citrus medica). Among all the citrus fruits produced either for export or local markets, sweet orange contributes 71 percent of the total citrus fruit production in world. Brazil is the largest producer of orange followed by USA. Oranges are the second largest fruit grown and processed in the world after grapes. Orange is the $3^{\text {rd }}$ largest producing fruit in India after mango and banana. The major orange producing states of India are Andhra Pradesh, Maharashtra, Karnataka, Punjab and Rajasthan. In Maharashtra, citrus is grown in the districts of Ahmednagar, Nasik, Pune, Parbhani and Latur on an area of 0.45Lakh ha. Nucellar Mosambi, Mudkhed seedless and Rajapui are the major cultivars of sweet oranges cultivated in Maharashtra. In Parbhani district, Nucellar, Mosambi local and Rajapimpari are the major cultivars of sweet orange.

The fruits of sweet orange (Citrus cinensis L.Osbeck) are sub globose to round or oval in shape, diameter ranges from 5.7 to $9.5 \mathrm{~cm}$, greenish yellow to orange in color and tightly skinned. The fruit have constituent about juice (40-50\%), flavedo (8-10\%) and albedo (15-30\%). The fruit consists of an outer peel, which includes epidermis, flavedo, oil glands, albedo and vascular bundles. The flavedo is outer yellow sub epidermal layer containing carotenoids pigments and numerous oil glands filled with aromatic essential oils. The albedo is the inner white spongy layer of parenchymatous cells closely adherent to outer wall of segment and thickness $(0.16$ to $1.43 \mathrm{~cm})$. It is rich in glucosides, flavonones, bitter principles, pectin and pectic enzyme. The thread like vascular bundles from albedo form a network running parallel to the fruit axis along the outside of the segments. It is rich in peroxides. The inner flesh consists of 10-12 segments, distributed around of pithy core forming central core of fruit. Each segment is surrounded by thin wall carpellary membrane called septum. The juice sacs are closely compacted, clubshaped vesicles, which completely fill the segments and are attached to the walls with small hair- like papillae. Segments of most sweet orange varieties contain 1 to 3 or 4 seeds attached by means of placentae to the septum wall. The seeds are rich in oil (30 to 40\%) and bitter limonoids.

Citrus fruit processing produces many byproduct with significant value. These wastes could be used for the production of many phytochemical, pharmaceuticals, food products, food products, essential oil, seed oil, pectin and dietary fibers. These by-products are considered to be rich source of edible and health promoting agents as polymethoxylated flavonoids, many of which are found exclusively in citrus peel [1]. Orange peel remaining after juice extraction is the primary waste fraction almost $50 \%$ of fruit mass. Peel byproducts contain sugars, edible fiber and many other components that offer excellent opportunities as value-added products, particularly those components that have biological activities (antioxidant, anti-cancer, cardio protective and food/drug-interactions) or other attributes that are useful in the development of high-value food products from citrus peel [2]. Albedo layer white spongy layer below flavedo layer in orange peel is source of pectin. pectin produced from orange peel has wide spread application in food industry as gelling in jam and jellies, thickening, texturizing, emulsifier and stabilizing agents in dairy products, fruit preparation or in icings and frostings. It is generally produced by acid extraction followed by filtration and precipitation by alcohol. Flavedo

*Corresponding author: Girish Marotirao Machewad, Department of Food and Industrial Microbiology, College of Food Technology, Marathwada Krish Vidyapeeth, Parbhani-431 402, Maharashtra, India, Tel: +91 02452-222468; Fax: +91-02452-234150; E-mail: gmachewad@rediffmail.com

Received August 14, 2012; Published September 10, 2012

Citation: Hashmi SH, Ghatge P, Machewad GM, Pawar S (2012) Studies on Extraction of Essential Oil and Pectin from Sweet Orange. 1:291. doi:10.4172/scientificreports.291

Copyright: @ 2012 Hashmi SH, et al. This is an open-access article distributed under the terms of the Creative Commons Attribution License, which permits unrestricted use, distribution, and reproduction in any medium, provided the original author and source are credited. 
Citation: Hashmi SH, Ghatge P, Machewad GM, Pawar S (2012) Studies on Extraction of Essential Oil and Pectin from Sweet Orange. 1:291. doi:10.4172/scientificreports.291

Page 2 of 3

\begin{tabular}{|c|c|}
\hline Characteristics & Value \\
\hline Color & Greenish yellow \\
\hline Wt of fruits $(\mathrm{g})$ & 199.00 \\
\hline Diameter $(\mathrm{mm})$ & 84.06 \\
\hline Thickness of peel $(\mathrm{mm})$ & 2.34 \\
\hline Wt. of peel $(\mathrm{g})$ & 47.10 \\
\hline Wt of albedo $(\mathrm{g})$ & 31.69 \\
\hline Wt of Flavedo $(\mathrm{g})$ & 15.39 \\
\hline Wt of fruit without peel $(\mathrm{g})$ & 167.25 \\
\hline Wt of juice $(\mathrm{g})$ & 77.65 \\
\hline Wt of Pomace $(\mathrm{g})$ & 66.00 \\
\hline Wt. of seeds & 12.60 \\
\hline No. of seeds & 17 \\
\hline
\end{tabular}

Each value is average of ten determinations.

Table 1: Physical characteristics of sweet orange

\begin{tabular}{|c|c|c|}
\hline Particulars & Quantity & Per cent \\
\hline Whole Fruit $(\mathrm{g})$ & 199 & 100 \\
\hline Peel $(\mathrm{g})$ & 47.1 & 23.66 \\
\hline Juice $(\mathrm{ml})$ & 81 & 37.95 \\
\hline Pomace $(\mathrm{g})$ & 63.9 & 32.09 \\
\hline Seed $(\mathrm{g})$ & 12.6 & 6.3 \\
\hline
\end{tabular}

Each value is average of ten determinations.

Table 2: Percent proportion of each part of sweet orange.

\begin{tabular}{|c|c|}
\hline Characteristics & Value \\
\hline \multicolumn{2}{|l|}{ Physical } \\
\hline Appearance & yellowish \\
\hline Flavour & Orange \\
\hline Relative density(g/ml) & 21.02 \\
\hline Specific gravity & 0.841 \\
\hline \multicolumn{2}{|l|}{ Solubility in ethyl alcohol } \\
\hline$(95 \%)$ & Soluble \\
\hline$(90 \%)$ & Insoluble with haziness \\
\hline Yield (\%) & 3.02 \\
\hline Evaporation residue (\%) & 4.25 \\
\hline Flash point & $48^{\circ} \mathrm{C}$ \\
\hline \multicolumn{2}{|l|}{ Chemical } \\
\hline Peroxide value & 3.5 \\
\hline Aldehyde content (\%) & 1.3 \\
\hline Ester content (\%) & 2.0 \\
\hline
\end{tabular}

Each value is average of three determinations.

Table 3: Physicochemical characteristics of essential oil from flavedo layer of sweet orange.

layer means outer covering of peel is source of essential oil. Essential oil was one of the citrus by-products attracting keen interests of people. It is expressed from flavedo layer by methods mechanically pressing, steam distillation, super critical, solvent extraction. Expressed sweet orange oil is primarily used for flavoring beverages, soft drinks, ice cream, sweets, pharmaceutical preparations, and also perfumes [3]. Therefore the morphological characteristics, extraction and characterization of essential oil from flavedo layer and pectin obtained from albedo layer were studied.

\section{Materials and Methods}

The whole sweet orange fruits (variety Nucellar) were procured from Sweet Orange Research Scheme, Marathwada Krishi Vidyapeeth, Badnapur, Jalna, Maharashtra. The oranges were washed, wiped and then stored in the cold chamber $\left(10^{\circ} \mathrm{C}\right)$.

Determination of physicals characteristics of essential oil from flavedo and pectin from albedo layer of sweet orange peel

The physical characteristics of essential oil from flavedo and pectin from albedo layer of sweet orange peel such as appearance, odor, relative density, specific gravity, solubility in alcohol, evaporation residue and flash point ester content were determined as per standard procedure.

Determination of chemicals characteristics of essential oil from flavedo layer and pectin from albedo layer of sweet orange peel

The chemical characteristics of essential oil from flavedo and pectin from albedo layer of sweet orange peel such as peroxide value, aldehyde, ester content, moisture content, ash, degree of methoxylation, gel grade and calcium pectate were determined as per standard procedure [4].

\section{Results and Discussion}

The physical characteristics of sweet orange were found skin color (greenish yellow), average weight (199 g), average diameter $(84.06 \mathrm{~mm})$, thickness $(2.34 \mathrm{~mm})$, weight of peel $(47.1 \mathrm{~g})$, weight of flavedo (15.39 g), albedo layer (31.69 g), weight of fruit without peel (167.25 g), weight of $81 \mathrm{ml}$ extracted juice (77.62 g), weight of pomace ( $66 \mathrm{~g})$, weight of seed $(12.6 \mathrm{~g})$ and total number of seeds (17) (Table 1). The results obtained were in good agreement with the findings [5]. The percent of each part of sweet orange fruit were found peel (23.66\%), juice (37.95\%), pomace (32.09\%) and seed (6.3\%). The proportion of each part of sweet orange fruit were found weight of peel $(23.66 \%)$, juice $(37.95 \%)$, pomace (32.09\%) and seed (6.3\%) (Table 2).

\begin{tabular}{|c|c|}
\hline Characteristics & Value \\
\hline Yield (\%) & 20.12 \\
\hline Colour & Brown \\
\hline Moisture (\%) & 3.78 \\
\hline Ash (\%) & 0.62 \\
\hline Degree of methoxylation (\%) & 9.20 \\
\hline Gel grade (\%) & 150 \\
\hline Calcium pectate (\%) & 7.40 \\
\hline
\end{tabular}

Each value is average of three determinations.

Table 4: Physicochemical characteristics of pectin from albedo layer of sweet orange peel.

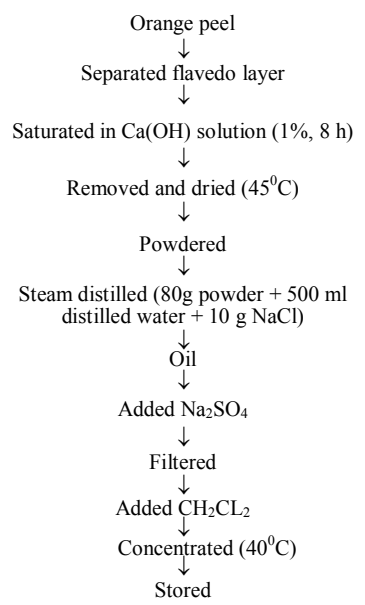

Figure 1: Flow sheet for preparation of essential oil from flavedo layer. 
Citation: Hashmi SH, Ghatge P, Machewad GM, Pawar S (2012) Studies on Extraction of Essential Oil and Pectin from Sweet Orange. 1:291. doi:10.4172/scientificreports.291

Page 3 of 3

$$
\begin{gathered}
\text { Orange peel powder } \\
\downarrow \\
\text { Added HCL }(0.05 \mathrm{~N}) \\
\downarrow \\
\downarrow \\
\text { Boiled (temperature } \left.100^{\circ} \mathrm{C}, 60 \mathrm{~min}\right) \\
\downarrow \\
\text { Cooled (room temperature) } \\
\downarrow \\
\text { Marc separated by filtration (twice) } \\
\downarrow \\
\text { Added absolute alcohol (double volume) } \\
\downarrow \\
\text { Separated the precipitate } \\
\downarrow \\
\text { Dried } \\
\downarrow \\
\text { Pectin }
\end{gathered}
$$

Figure 2: Flow sheet for extraction of pectin from albedo layer of sweet orange peel.

The yield of essential oil (3.02\%) is obtained from sweet orange flavedo layer. The results are in good agreement [3]. The physical characteristics of essential oil were found appearance (yellowish), flavour (orange), relative density (21.02), specific gravity $(0.841 \mathrm{~g} / \mathrm{ml})$, solubility $(90 \%$ and $95 \%)$, evaporation residue $(4.25 \%)$, flash point $\left(48^{\circ} \mathrm{C}\right)$. The chemical characteristics such as aldehyde and ester content were $1.3 \%$ and $2.0 \%$ respectively (Table 3 ). The results are in good agreement [6]. The physicochemical characteristics of pectin obtained from dried albedo peel layer of sweet orange were found yield $(20.12 \%)$, moisture $(3.78 \%)$, ash $(0.62 \%)$, degree of methoxylation $(9.2 \%)$, gel grade $(150 \%)$ and calcium pectate $(7.40 \%)$ (Table 4$)$. The degree of methoxylation was slight differ [7]. The degree of methoxylation was in the range $8-12 \%$ for citrus fruits [8]. Finally it can be concluded that the flavedo and albedo layer of sweet orange can be utilized for preparation of essential oil and pectin.

\section{References}

1. Hatamipour MS, Majidi SM, Abdi M, Farbodnia (2004) Potentials for industrial utilization of citrus byproducts, CHISA 2004. Proceedings of the $16^{\text {th }}$ International Congress for Chemical and Process Engineering, 22-26 Aug, Prague, Czech Republican, pp. 9263.

2. Widmer WW, Montanari AM (1994) Citrus waste steams as a source for phytochemical. Proceedings of the Florida, State Horticulture Society 107: 284288.

3. Tao NG, Liu YJ, Zang JH, Zeng HY, Tang YF (2009) Chemical composition of essential oil from the peel of satsuma mandarin. African J Biotech 7: 12611264.

4. AOAC (2000) Official Methods of Analysis (17th Edn.), Official Methods of Analysis of Association of Official Agricultural Chemists International, Gaithersburg, MD.

5. Siddiqi NA (2005) Debittering of sweet orange by resin. M. Tech. Thesis, College of Food Technology. Marathwada Krishi Vidyapeeth, Parbhani, Maharashtra, India.

6. Muhammad MA, Salim-ur-Rehman (2006) Sensory evaluation of citrus peel essential oils as flavoring agents in various food products. J Agric Res 44: 325333.

7. Tamaki $Y$, Konishi $T$, Tako $M(2008)$ Isolation and characterization of pectin from peel of citrus tankan. Biosci Biotechnol Biochem 72: 876-881.

8. Apsara M, Pushpalatha PB (2002) Characterization of pectin extracted from different fruit wastes. J Tropical Agril 40: 53-55. 